

\section{Abstract}

The growing recognition that happiness and well-being are intertwined with sustainability is leading to new opportunities for enhancing happiness and well-being, sustainably. The education sector has a critical role in advancing this work but has been slow to incorporate sustainability education and applications of positive psychology. The concept of sustainable happiness (happiness that contributes to individual, community and/or global well-being without exploiting other people, the environment or future generations) (O'Brien, 2010a) offers an innovative perspective to re-invigorate sustainability education and shape priorities for $21^{\text {st }}$ century learning - contributing to resilient, sustainable happiness and well-being for all.

Keywords: sustainable happiness; sustainable well-being; education; positive psychology 


\title{
Who is Teaching Us about Sustainable Happiness and Well-Being?
}

\author{
C. O'Brien
}

\section{Introduction}

Children growing up in North America over the last ten years are being immersed in a culture that is enthralled with happiness. From happy shampoos to happy pet food, commercial products are being associated with happiness. Coca Cola's "happiness truck" and Cadbury's campaign to capture the sounds of joy in New Zealand are capitalizing on the popular buzz about happiness. Thousands of books, magazines, blogs and talks shows discuss the secrets to happiness, building on the research from positive psychology and happiness studies. Beyond the pop culture, happiness research has attained sufficient credibility for many governments to acknowledge that happiness and well-being should be considered in the formulation of national policies (CIW, 2009; Helliwell et al, 2012; Stiglitz et al, 2009). However, three decades ago, prior to the emergence of positive psychology, Bhutan's king was ahead of the curve when he proclaimed that Gross National Happiness (GNH) is a more relevant indicator of wellbeing than Gross National Product. In July of 2011, Bhutan spearheaded a United Nations (UN) resolution recommending that member states give greater attention to happiness and well-being in their economic and social development policies (UN, 2011). The resolution was adopted by all of the 193 UN member states (Thinley, 2012) and lays the foundation for further work that links sustainability, development, happiness and well-being.

Building on the UN resolution, Bhutan's Prime Minister, Jigmi Y. Thinley, hosted a high level meeting at the United Nations in New York on April $2^{\text {nd }}, 2012$ with 700 invited delegates who were convened to discuss a new economic paradigm for realizing a world of sustainable well-being and happiness (Royal Government of Bhutan, 2012). Thinley (2012) wrote at that time about the need for a new economic paradigm that links sustainability and happiness. "Sustainability is the essential basis and precondition of such a sane economic system. An economy exists not for mere survival but to provide the enabling conditions for human happiness and the well-being of all life forms" (p. 64).

The April $2^{\text {nd }}$ meeting brought sustainability experts together with positive psychologists and other academics that are researching happiness and well-being. The World Happiness Report that was launched to coincide with the event accentuates the relevance of happiness studies for sustainability as well as the broad benefits of realigning economic activity to contribute to well-being, sustainably (Helliwell et al, 2012). The World Happiness Report is an important contribution to the small, but expanding, body of literature that is establishing the merits of decoupling happiness and life satisfaction from over consumption. Kasser (2006) explored materialism and the good life while the New Economics Foundation created the Happy Planet Index (HPI) to answer such questions as, "does happiness have to cost the earth?" Or, in other words, can we live long and happy lives within the resource capacity of the planet? In essence, investigating sustainable well-being for all. Measures of experienced well-being, life expectancy and the Ecological Footprint for each country studied are used to calculate the current HPI. The most recent HPI report (Abdallah et al, 2012) determined that Costa Rica is achieving the best balance out of 151 
countries while the USA's high Ecological Footprint brought it to the 105th position. If every country had a similar Ecological Footprint to the USA, it would require four planets to meet this level of consumption.

This growing awareness that sustainability, happiness and well-being are intertwined takes the discussion of happiness (and sustainability) to new levels - with significant relevance both individually and collectively. It also creates an interesting and important counterpoint to the portrait of happiness that has been associated with material consumption. Happiness is at the heart of who we are and what we do but in a consumer society, where consumption and happiness are often entangled, individuals may confuse the "path to the 'good life' as the 'goods life"' (Kasser, 2006, p. 200). Even though scholars and governments are now grappling with questions about policies for sustainability, happiness and well-being, the general public may not be aware of these connections and none of these topics are well integrated into formal education. Nevertheless, the necessity for transforming education to play a leading role in sustainability education has never been more imperative.

\section{Time Sensitive Dilemma}

We have a pressing time sensitive dilemma to resolve. On a global scale, our societies are on an unsustainable trajectory that must be radically altered and has already led to unfathomable human suffering and severe ecological damage. In fact, by 2007, humanity's Ecological Footprint had already exceeded the earth's biocapacity by 50\% (Moran and Wackernagel, 2012) and we are in a state referred to as 'ecological overshoot,' meaning that we continue to use the earth's resources faster than they can be replenished. Orr (2012) suggests that the timeline is shrinking to address the extensive challenges that humans have set in motion and that "we have good reason to believe that this will be the closest of close calls" (Orr, 2012, p. 48). At the individual level and the national level we simply have not made sufficient efforts or progress towards sustainability so it becomes difficult to remain optimistic that humanity will rise to the challenge. The UN Secretary-General's report, Resilient People, Resilient Planet: A Future Worth Choosing (2012) noted that "progress has been made, but it has been neither fast nor deep enough, and the need for further-reaching action is growing ever more urgent" (p.6).

Given the severity of issues such as climate change, loss of biodiversity, deforestation, and desertification, it is understandable that sustainability experts might consider a focus on happiness as a diversion from the serious work that needs to be done. It could also be argued that a preoccupation with individual happiness presents a danger that will exacerbate sustainability efforts if the general public embraces marketing messages that equate happiness with material consumption.

Skeptics of happiness research could point to the rankings of the happiest countries and happiest cities. These measures provide useful information about the factors that contribute to happiness and well-being which can help to reshape policies that foster well-being. However, the surveys typically fall short of raising awareness that life satisfaction declines with over consumption of natural resources or inequitable trade practices (Royal Government of Bhutan, 2012) and thus may convey incomplete information. As demonstrated through the HPI, a country's elevated life satisfaction may also be accompanied by a high Ecological Footprint, though this isn't the development model to emulate. Furthermore, the press coverage of the happiest cities and nations rarely acknowledge that the prosperity of these happy people and happy places may be derived through centuries of exploitation and unsustainable economic development.

Here's an alternate vision. We could enhance sustainability initiatives by raising awareness that our happiness and well-being are intertwined with the happiness and well-being of other people, other species and the natural environment (O'Brien, 2005). That's the intention behind the concept of sustainable happiness, defined by O'Brien (2010a) as happiness that contributes to individual, community and/or global well-being without exploiting 
other people, the environment or future generations. This is aligned with the UN resolution on happiness and wellbeing and can be applied to individual lifestyles, community planning, national policies, and international agreements.

In my experience, sustainable happiness can be used to foster sustainable lifestyles (O'Brien, 2012b; Scott, 2009). In fact, our natural desire for happiness becomes the entry point for discovering that our well-being is inextricably associated with the well-being of others and the natural environment. This concept can also dispute a common misconception that living sustainably will lower our quality of life. Brown and Kasser (2005) suggest that "as long as environmentally responsible behaviour is framed in self-sacrificial terms, individuals will be faced with tough choices about how to act" (p. 349) because such behavior is assumed to detract from happiness. Sustainable happiness invites opportunities to enrich our quality of life and contribute to individual, community, and global well-being. For example, each of us has numerous decision points throughout the day where we can make choices that contribute to, or detract from, well-being. Consider a cup of coffee that could be fair trade (or direct) coffee and thus ensures that the plants were grown with care for the environment and workers were paid fairly. Choosing sustainable modes of transportation to work or school (walking, cycling, and transit) is better for human and environmental health. Making time to spend with family and friends, volunteering in the community, donating clothes to clothing banks, can all enhance well-being and are consistent with the spirit of sustainable happiness. Imagine the most livable cities and it's clear that these are contributing to sustainable happiness through public parks, bicycle paths, diverse landscapes, greenspaces, sustainable transportation, trails, farmers' markets, healthy environments, and public events that build community cohesion.

How do we get from where we are to a more sustainable future? There are many paths and countless levels of engagement required. Education has a central role to play - raising awareness and inspiring innovation for happier, healthier and more sustainable societies. I'm referring to both formal education and the non-formal education that is needed to reach the general public, decision makers, and business leaders - all members of civil society.

That raises the further question: is the education sector up to the task?

\section{Who is teaching us about sustainable happiness?}

Unfortunately, formal education itself is not demonstrating exemplary leadership in sustainability. In a survey of current practice, a UNESCO report (2005b) questioned whether education is part of the problem or the solution.

\footnotetext{
We are faced with a paradox: Is education the problem or the solution in working toward a sustainable future? At current levels of unsustainable practice and over consumption it could be concluded that education is part of the problem. If education is the solution then it requires a deeper critique and a broader vision for the future. Thus, whole systems redesign needs to be considered to challenge existing frameworks and shift our thinking beyond current practice and toward a sustainable future. (p. 57)
}

More recently, a survey of Canadian faculties of education that investigated the implementation of Education for Sustainable Development (ESD) found that few faculties have explicitly implemented ESD-related courses though some implicit actions have been taken (Swayze et al, 2012). This means that despite the fact that there are superb resources for sustainability education (used here interchangeably with ESD), we are not adequately training teachers to model and practice sustainability. Additionally, too often, environmental education tends to be viewed as simply a subject and our schools are not offering the applied, experiential learning that fosters sustainable lifestyles. Therefore, the opportunity for formal education to nurture critical thinking about happiness and 
sustainability (for students and teachers) has not been seized. And yet the potential for bringing these two together is quite powerful.

As a sustainability educator, I was frankly inspired by the early research that emerged from positive psychology. There were clear indications that happiness, subjective well-being and life satisfaction have numerous health and well-being benefits (Davidson, Mostofsky and Whang 2010; Seligman, 2002; Steptoe, Wardle, and Marmot, 2005; Veenhoven, 2006), with happy people demonstrating lower inclination toward materialistic values (Brown and Kasser, 2005). There also appear to be implications for sustainable lifestyles as Turcotte (2006) found that individuals who actively commute to work enjoy their commute more than those who use motorized transportation - though we don't know whether the active commuters have greater life satisfaction overall because they have more opportunities to make these kinds of lifestyle choices - they may have the income to be able to reside closer to work, for example. Barton and Pretty (2010) found an association between green exercise and positive emotions. More recently, (Ramanathan et al, 2012) found that children, and their parents, who travel actively to school report more positive emotions than those who travel using passive modes, such as motorized transportation.

However, despite these promising findings for sustainability, positive psychologists, for the most part, were not initially drawing connections to sustainability, nor were sustainability experts recognizing the potential from happiness studies. Rather, the emphasis of environmental education was, for some time, more focused on raising alarms about the scope of our environmental challenges and communicating this in what many would call "doom and gloom" messages (Kelsey and O'Brien, 2011). There's no doubt that the severity of ecological degradation and exploitation demand heightened attention and action. Certainly, there has been a shift in environmental awareness with some progress toward more sustainable lifestyles but the time is ripe for a transition from a problem focus to a solution focus that stimulates creative and compassionate responses that are hopeful rather than instilling fear of impending disasters.

In contrast, building on the widespread interest in happiness and pairing it with sustainability through sustainable happiness is a compelling education and communication strategy for taking happiness discussions and research in new directions and re-invigorating sustainability education. See O'Brien (2012a, 2012b) for a discussion of how this is happening at the post-secondary level and recommendations for teacher education.

Turning our attention to children and youth in grades kindergarten to grade twelve, we could ask who (or what) is teaching them about happiness and what are they learning? Is it likely to reflect sustainable happiness? I've asked high school students informally: who or what taught them about happiness and has that changed from the time they were children? Their response was that their parents had the greatest influence on them during their childhood and to some extent their toys, pets and Sesame Street. However, now, as young adults, it's the media and their peers that have the strongest influence. We can safely assume that the media is quite a pervasive influence as studies of North American youth screen time usage indicate that many students are spending more hours on the three screens (smartphone, computer and television) than they are in the classroom (Leatherdale and Ahmed 2011; Rideout et al, 2010). It's reasonable to deduce that their media usage has an impact on their consumption patterns and may in fact be shaping their understanding of happiness.

A joint UNESCO and UNEP (United Nations Environment Program) study (Nyberg and Stø, 2001) surveyed youth in 24 countries to discover their views on their own consumption. The young people were asked to indicate their level of agreement with the following statements:

It is important for me to have a lifestyle compatible with that of my friends.

People of my age are consuming too much (me included!).

Who is Teaching Us about Sustainable Happiness and Well-being?

Volume 5, No. 1 (2013) | ISSN 2161-6590 (online) | DOI 10.5195/hcs.2013.122 | http://hcs.pitt.edu 
It is the first time I had to think about my own consumption.

Consuming efficiently is part of my values.

Having more would still make me happier.

Sixty percent agreed that people of their own age are consuming too much, and forty-four percent had the view that they would be happier if they had more. Nyberg and Stø (2001) noted that the youth were aware of many environmental issues but did not recognize the relationship between their consumption patterns and the potential environmental impact (nor the impact on other people). Ten years later, the Global Survey on Sustainable Lifestyles, (GSSL) surveyed 8,000 young adults (ages 18-35) living in urban areas in 20 countries (UNEP, 2011) and also found that they were not well informed about the impact of their consumption patterns and the opportunities that they have to make a positive difference as consumers. Nevertheless, they are "willing to participate and improve the world they live in through more sustainable lifestyles. They need to know how and be given opportunities to take concrete actions." (p. 72). UNEP et al (2010) developed an education resource on sustainable consumption and encourage educators to integrate activities and reflection on sustainable consumption into the curricula. A unique resource for educators, Lessons in Sustainable Happiness, provides the rationale for incorporating sustainable happiness into existing curricula and provides lessons to facilitate the process (O’Brien, 2013).

In summary, sustainability education is not broadly practiced, despite the fact that we are coming to the end of the UN Decade on Education for Sustainable Development (UNESCO, 2005a) which has steadfastly supported global initiatives to embrace sustainability education. Consumption levels, particularly of the world's middle classes, are exerting unprecedented pressure on the environmental resources that sustain us. The Rio+20 document, Resilient People, Resilient Planet: A Future Worth Choosing (2012) outlined it like this:

The conjunction of a growing "global middle class" with unsustainable patterns of consumption threatens to push us inexorably towards the limits of natural resources and planetary life support systems - from food, water and energy resources to global systems such as the oceans, the climate and the nitrogen cycle. Without major changes, the planet's capacity to support and sustain us will continue to degrade, with the potential for sudden shifts as key thresholds and tipping points are passed, and as social pressures for fairness increase. (p.35)

The report continues with recommendations for changing this scenario, including making "sustainable choices available, affordable and attractive to consumers"(p.35). Education that assists people to understand the human and environmental impact of their choices is fundamental - and possibly more importantly, inspires them to act on that knowledge. This transformational education is being achieved through courses on sustainable happiness, which assist students to discover opportunities for shifting their consumption. This student, for example, attempted to have a "Buy Nothing Day" which means not purchasing anything for a day:

For the shifting consumption activity, I had decided early on I would have a "Buy Nothing" day because I felt it would be the easiest to do and I would see the money I would save, which would influence my future spending. However, not buying anything for one day proved more difficult than I had originally thought. For close to one week I tried different days to go without buying anything, but it always seemed like I ended up 
buying things without even realizing I was spending![...] This made me realize how unconsciously I spend money [...] I came to the conclusion that much of our spending is senseless and wasteful, and it is activities such as this one that get people thinking about the effects of this spending. I think activities such as this shifting consumption activity are just one step toward changing society's attitudes toward spending, because I know it has changed my attitude and made me more aware of my actions.

(Student comment after completing Buy Nothing Day activity, 2012)

\title{
III. Positive Psychology Goes to School
}

Positive psychology has been making inroads into the formal education sector leading to the introduction of new terms such as 'positive education' and programs that work with character strengths and virtues (Boniwell and Ryan, 2012; O’Grady, 2013; Seligman, 2011). Seligman et al (2009) defined positive education as "education for both traditional skills and for happiness." Educators who have recognized the extensive applications of positive psychology for the promotion of school health and student well-being have also adopted the phrase 'positive schools' (Joint Consortium for School Health [JCSH], 2008; Morrison and Peterson, 2010; New Brunswick Department of Wellness, Culture and Sport, 2011) and resources such as the Positive Mental Health Toolkit (Morrison and Peterson, 2011) have been developed. However, (similar to sustainability education), positive psychology and happiness research have not been integrated into public school curricula or teacher training despite the considerable merits of doing so (Conoley \& Conoley, 2009; O’Brien, 2012b; Seligman, 2011). Teacher training is a key place to start.

The sustainable happiness course, mentioned above, is offered as an elective in the teacher education program at Cape Breton University (Canada). It introduces student teachers to positive psychology and uses experiential learning to explore happiness and well-being. For example, the first assignment prompts students to interview the happiest person they know. The interview is carried out before students complete readings on happiness research. Generally this activity reveals that the "happy" people who were interviewed have made conscious choices about their happiness and well-being, often overcoming adversity. Subsequently, students compare their interview results with evidence from happiness research. Another assignment focuses on gratitude and appreciation. Students have the option to express gratitude through a letter, a journal or through artistic expression such as poetry, visual arts, and songwriting. Composing and delivering a gratitude letter is the most popular choice and the recipients tend to be parents, grandparents, friends, significant others, and former teachers who have had a deep impression on them. The letters often have quite profound and moving results. The most novel letter to date has been one that was addressed to the 11,000 volunteers with Canada Post who respond to letters sent to Santa Claus, care of the North Pole. One student wrote to her mother and summarized her experience like this:

\begin{abstract}
My letter consisted of many overdue thanks, apologies and confessions. I was surprised at how emotional of an experience this letter writing activity was. I had treated it like a free-write activity where I started writing with one thought in mind and then allowed the thoughts to flow freely onto the page as they came [...] After writing this letter, I feel exponentially better about my life and my control over it. I have come to realize that I have the ability to choose how particular events will affect me.
\end{abstract}

(Student comment after completing Gratitude activity, 2012)

\section{Sustainability Education and Positive psychology}

Both sustainability education and positive psychology have the intention of contributing to well-being. Sustainability education has a much broader scope as it involves human and environmental health and well-being. However, as noted previously, sustainability education would be enriched and possibly more effective if it integrated 
perspectives from positive psychology. Proponents of positive education and positive schools are offering a refreshing contribution to education. Students and society will most certainly benefit from greater attention to student wellness, illness prevention, and happiness skills for enhanced resilience (Seligman, 2011). This would be a progressive step forward but still grossly insufficient to foster the massive shift in values and behavior that are required to make a transition towards a more sustainable future - which ultimately impacts everyone's well-being. O'Brien (2012b) recommended the integration of positive psychology and sustainability education into teacher education and throughout the formal education curricula. This would engage students and teachers in a deeper understanding of how to live and work, respecting their own well-being and the well-being of other people, other species, the natural environment, and future generations. It would assist students to understand how their consumption patterns contribute to, or detract from, well-being and thus augment education for sustainable consumption. Sustainable happiness is an ideal fit for this proposed merge.

Readers who are interested in health promotion may be intrigued to learn that the sustainable happiness course that is offered to student teachers at Cape Breton University has motivated students to examine their lifestyles through the lens of both sustainability and well-being. This motivates many students to make healthier lifestyle choices. The course concludes with a sustainable happiness project and this culminating activity helps to solidify the value of healthy, sustainable lifestyles. The sustainable happiness projects are diverse and always fascinating. Some students choose to focus on their own well-being, something that they have lost sight of as they strive to manage full-time studies with part-time work and even the demands of a family. Others have sought to improve relationships with loved ones, generally by spending more time together. One student created a "Buy Nothing Week" challenge that united her family in surprising ways. She wrote:

\footnotetext{
The biggest thing that changed is that we as a family started to actually communicate [...] we started to spend more time together. My father and I even got a chance to play a few games of cribbage which rarely happens. The biggest shocker of all was the change in meal times. We are all busy and recognized that going out for food was the biggest expense for us all on a weekly basis. On Sunday, my mother made dinner and we actually all sat down for a meal together [...] That only happens twice a year, Christmas and Thanksgiving, so it was definitely the highlight of the whole experience.
}

(Student comment after completing Sustainable Happiness Project, 2012)

A mature student with a young daughter and teenage son devised a plan that would involve more quality family time. They rented ice time at the local rink, played board games, and went out for dinner together. She shared the positive impact that this had on their relationships.

Doing this project made me really step aside and think about how we are constantly rushing trying to get everything done and we are missing out on some of the best moments in life. This was very important to me because this is [my son's] last year of high school and after this we will see even less of him. There is nothing I love more than my family and spending time with them brings me the greatest joy.

(Student comment after completing Sustainable Happiness Project, 2012)

A student, living in residence, chose to create a cell-phone free zone for herself and her friends with the aim of improving their communication and raising awareness about the influence of technology in their lives. She met with some resistance as friends tried to "sneak a peek" at their phones at first but eventually they committed to her request to honor the cell-phone free area for the weekend. She was delighted with the transformation that occurred. 
Not only did people realize even more that they overuse their phone but they started being more productive.

We played board games and watched movies together with no interruption of texting or Facebooking.

(Student comment after completing Sustainable Happiness Project, 2012)

The sustainable happiness project inspired one student to set short term and long term lifestyle goals. Note that her plan to increase the amount of sleep she is getting is still short of a full 8 hours but is apparently an improvement.

Lifestyle Goals:

- $\quad$ Get at least 5.5 hours sleep nightly

- Eat breakfast in the morning before leaving the house

- $\quad$ Take personal time for self every day

- Eat healthier

- $\quad$ Eat three meals a day

- $\quad$ Produce less waste

- $\quad$ Consume less energy

At the conclusion of the project she wrote that:

I think more critically about my purchases than I ever have before. Every time I drive by a Tim Horton's [coffee shop], pick up an apple at the grocery store, stop to put gas in my car, I find myself considering the others that my decisions are affecting either directly or indirectly. I am more aware of the impacts of my decisions and the true depths of their reach. Overall, I have become a happier, more informed person, with the sound understanding that each choice I make has far reaching effects, beyond what I had ever previously imagined.

(Student comment after completing Sustainable Happiness Project, 2012)

The student above tackled her own lifestyle challenges. It may be more complex to tackle the lifestyle changes of the entire family but this particular student was very pleased with the results:

I can honestly say to me this project made me feel so good knowing I was doing something great for my family and their health. This project opened my eyes tremendously and I can't believe how easy it was to completely neglect our health and totally not notice doing it. I also can't believe how hard it was to get back in the routine of healthy living. The changes we have made as a family are definitely here to stay and every one of us can honestly say overall we genuinely feel better and this is just the start to our new way of life we are already brainstorming phase two of our healthy lifestyle challenge.

(Student comment after completing Sustainable Happiness Project, 2012)

Another student who decided to re-examine her priories to create healthier choices and a better work-life balance wrote: 
I feel incredible! I have had time to do everything I love. I now eat better, I exercise, I spend time with my family, I finally have time to sit and read, and I have time to relax and not have a worry in the world to think about. I have no idea why I stopped doing everything that made me happy, working and school were my only priorities. This last week every night going to bed I was extremely happy and had the best sleep I ever had in a very long time. Waking up every day with a smile made each day better and better for myself and everyone around me. I will continue with this project hopefully for the rest of my life and everyday make sure I tell the important people in my life how much I care and love for them.

(Student comment after completing Sustainable Happiness Project, 2012)

My sense is that the sustainable happiness course is transformational. Students come to very significant insights about happiness and well-being and enthusiastically embrace the benefits of choosing healthier, and more sustainable lifestyles. It's encouraging to imagine that these new teachers will have the knowledge and skills to integrate sustainability education, positive psychology and sustainable happiness into their personal and professional life. Far greater impact would be achieved if the education sector embraced sustainable happiness, incorporating it into policies, curricula, teacher training, school sitting, and school designs.

\section{IV. $\quad 21^{\text {st }}$ Century Learning}

Education journals, books, blogs and conferences are actively debating education reform, how to transform education to meet $21^{\text {st }}$ century learning needs, questioning the role of education and how to scale up the best practices of education leaders. Traditional education is criticized for being outdated, stuck in patterns that were suitable for the industrial age (Hargreaves and Shirley, 2012; Robinson, 2009, 2011), too slow to embrace the digital literacy that is vital for student success (C21 Canada, 2012; Khan, 2012), or stifling creativity and innovation (Robinson, 2011). The pervasive practice in North America of focusing on assessing student (and school) achievement in science, literacy and numeracy through standardized testing has discouraged educators, particularly in schools that are not experiencing high levels of academic success, leaving teachers feeling beleaguered and possibly no longer believing that progressive change is possible (Fullan, 2010).

Teachers are also noticing that there are increasing incidences of anxiety in students and numerous high school teachers have commented that they're concerned about youth apathy. They describe their students as people who don't seem to care about anything - not themselves, their studies, their community, let alone the environment. It's heartening to hear about schools that have managed to turn these trends around and engage their students. Moncton High School (New Brunswick, Canada) introduced a school-wide program rooted in sustainability principles, with particular attention to individual and community well-being. Students were able to choose from an assortment of fifty activities such as a running club, creating their personal wellness plan, knitting hats for premature babies, and volunteering at a soup kitchen. The most popular item, for both girls and boys, was knitting. A principal in St. John's, Newfoundland tackled the multiple challenges in her school with a focus on social and emotional learning, including a dedicated commitment from the staff to ensure that every student is personally greeted as they enter the school. Her school team has realized that home life is seamlessly connected to the student's readiness to learn and students need various levels of support - whether it's breakfast or a sympathetic ear. How do they know when they are being successful, I asked. "We've got soul!" the principal responded with a radiant smile. The students at her school like coming to school, like their teachers, and the teachers are also happy in their work.

These examples demonstrate that with concerted effort, schools can be places where students and teachers thrive but this is the result of extraordinary leadership rather than an inherent quality of education. It's evident that educational change is sorely needed, for the well-being of students and teachers, for human and environmental 
health and well-being, and to play a more substantial role in sustainability education. While there isn't a one-sizefits-all package that will work for every country and school district, we are unlikely to gain traction in a healthier direction with the current multitude of visions for educational reform. Many visions, have not incorporated sustainability and basically want to ensure that students are prepared for success in a fast changing world presumably contributing to the outdated and unsustainable economic activity that prevails. Fullan (2010) points out, in All Systems Go, the factors that will (and have) been essential for whole-system reform:

All systems go means that every vital part of the whole system - school, community, district, and government contributes individually and in concert to forward movement and success. When it works, and I am talking practically, amazing things get accomplished with less effort; or more accurately, wasted effort gives way to energizing action. (p. 3)

He offers seven "Big Ideas" for whole-system reform: all children can learn; a small number of key priorities; resolute leadership/stay on message; collective capacity; strategies with precision; intelligent accountability; all means all (p.4). Each of these ideas merits a full discussion but let's focus further on "a small number of key priorities." This presumes that there is a clear vision that has shaped the key priorities. Proponents of $21^{\text {st }}$ century learning competencies or skills have offered views for modernizing education (Action Canada, 2013; C21 Canada, 2012; P21, 2011) with superb recommendations. Action Canada states that "the objective of 21st century learning is to build capacity in areas that promote a resilient society capable of effectively adapting to rapid change"(p.3). This is a statement that could readily be endorsed. However, if the aim is to maintain our world ranking as a country with a "highly-skilled labour force and competitive industries," (p.3) with no reference to sustainability then we may become more effective educators of a generation that perpetuates unsustainable consumption - reflecting the UNESCO query about whether education is part of the problem or part of the solution. There is similar promise and potential drawbacks to the promotion of entrepreneurship education (European Union, 2013). At the time of writing, C21 Canada is working toward incorporating sustainability into its vision. This is an important step towards a more comprehensive vision that could shape a bold and innovative direction for education in Canada, a country that is already a recognized leader in education (Fullan, 2010; Hargreaves and Shirley, 2012; OECD, 2011). A further step could involve integration of the excellent work regarding health promoting schools (HPS) (Stewart-Brown, 2006) and positive school health (Morrison and Peterson, 2010, 2011) as well as the essential contributions from experts in social and emotional learning (CASEL, 2008).

Ten years ago, Noddings (2003) recommended that, "happiness should be an aim of education, and a good education should contribute significantly to personal and collective happiness"(p.1). Broadening this recommendation to consider sustainable happiness and well-being for all, we readily have an overarching aim that could assist us to reimagine the role of education in the $21^{\text {st }}$ century and serve as the foundation for setting new priorities. This is also consistent with the discourse around a new economic paradigm that contributes to sustainable well-being and happiness (Royal Government of Bhutan, 2012).

Our education systems do not exist in isolation from the rest of society. They reflect our cultural values, but the education sector tends to be conservative, slow to adapt and rarely leads social change. That profile can be strength as we would not serve society nor our students well if we adopted every new educational trend. However, it also poses a barrier to progressive transformation. We need to find a better balance between the conservative profile and the impetus to bring education into the $21^{\text {st }}$ century. The active discourse about new visions for education is encouraging. Harnessing the strengths of all these visions has never been more timely nor more exciting as there appears to be a broadly accepted recognition that change is needed. Education can indeed become part of the solution - contributing to resilient, sustainable happiness and well-being for all. 


\section{References}

Abdallah S., Michaelson, J., Shah, S., Stoll, L., \& Marks, N. (2012). The happy planet index 2012: A global index of sustainable well-being. London: nef. http://www.happyplanetindex.org/assets/happy-planet-index-report.pdf.

Action Canada (2013). Future tense. Adapting Canadian education systems for the $21^{\text {st }}$ century. http://www.actioncanada.ca/en/wp-content/uploads/2013/02/TF2-Report_Future-Tense_EN.pdf.

Barton, J., \& Pretty, J. (2010). What is the best dose of nature and green exercise for improving mental health? A multi-study analysis. Environmental Science \& Technology 44, 3947-3955. http://www.greenexercise.org/pdf/the\%20best\%20dose\%20of\%20Ge\%20for\%20mental\%20health.pdf

Boniwell, I., \& Ryan, L. (2012). Personal well-being lessons for secondary schools. New York: McGraw Hill.

Brown, K., \& Kasser, T. (2005). Are psychological and ecological wellbeing compatible? The role of values, mindfulness and lifestyle. Social Indicators Research, 74, 349-368.

Collaborative for Academic, Social, and Emotional Learning. (CASEL). (2008). Connecting social and emotional learning with mental health. http://casel.org/wp-content/uploads/SELandMH.pdf.

C21 Canada (2012). Shifting minds: A $21^{\text {st }}$ century vision of public education for Canada. http://www.c21 canada.org.

Canadian Institute of Wellbeing (CIW). (2009). How are Canadians REALLY doing? First report of the Institute of Wellbeing. http://www.ciw.ca/en/ResourcesAndDiscussion/Reports.aspx.

Conoley, C., \& Conoley, J. (2009). Positive psychology for educators. In R. Gilman, E. Huebner, \& M. Furlong. (Eds.), Handbook of positive psychology in schools. New York: Routledge, 463-476.

Davidson, KW., Mostofsky, E., \& Whang, W. (2010). Don't worry, be happy: Positive affect and reduced 10-year incident coronary heart disease: The Canadian Nova Scotia Health Survey. European Heart Journal, 1065-1070. http://europepmc.org/abstract/MED/20164244/reload=0;jsessionid=C1Z3VlNvZspeOw5L1w9f.28.

European Union (2013). Entrepreneurship education: A guide for educators. Entrepreneurship and Social Economy Unit Directorate-General for Enterprise and Industry. http://ec.europa.eu/enterprise/policies/sme/promoting-entrepreneurship/files/education/entredu-manual-fv_en.pdf.

Fullan, M. (2010). All systems go. Thousand Oaks, CA: Corwin.

Hargreaves, A., \& Shirley, D. (2012). The global fourth way. Thousand Oaks, CA: Corwin.

Helliwell, J., Layard, R., \& Sachs, J. (Eds.) (2012). World happiness report. http://www.earth.columbia.edu/sitefiles/file/Sachs\%20Writing/2012/World\%20Happiness\%20Report.pdf.

Joint Consortium for School Health (JCSH). (2008). Investigating positive psychology themes in school health. http://www.jcsh-cces.ca/index.php/resources.

Kahn, S. (2012). One world schoolhouse: Education reimagined. New York: Hatchette Book Group.

Kasser, T. (2006). Materialism and its alternatives. In M. Csikszentmihalyi \& I. Csikszentmihalyi (Eds.), A life worth living: Contributions to positive psychology. Toronto: Oxford University Press, (200-214).

Kelsey, E., \& O’Brien, C. (2011). Sustainable happiness. Green Teacher, 93, 3-7. 
Leatherdale, S., \& Ahmed, R. (2011). Screen-based sedentary behaviours among a nationally representative sample of youth: Are Canadian kids couch potatoes? Chronic Diseases and Injuries in Canada, 31(4). http://www.phacaspc.gc.ca/publicat/cdic-mcbc/31-4/ar-01-eng.php.

Morrison, W., \& Peterson, P. (2010). Schools as a setting for promoting positive mental health: Better practices and perspectives. http://www.jcsh-cces.ca/index.php/resources.

Morrison, W. and Peterson, P. (2011). Positive mental health toolkit. Pan-Canadian Joint Consortium for School Health. http://www.jcsh-cces.ca/index.php/resources.

Moran, D., \& Wackernagel, M. (2012). Measuring sustainability. In J. Murray, G. Cawthorne, C. Dey, \& C. Andrew (Eds.), Enough for all forever. Illinois: Common Ground Publishing, 27-35.

New Brunswick Department of Wellness, Culture and Sport. (2011). Mental fitness: From evidence to action. www.acdccamc.ca/en/docs/Presentations/Mental\%20Fitness.pdf.

Noddings, N. (2003). Happiness and education. New York: Cambridge University Press.

Nyberg, A. and Stø, E. (2001). Youth sustainable consumption patterns and life styles: Management of social transformations. http://www.unep.fr/shared/publications/pdf/WEBx0067xPA-YouthSC.pdf.

O'Brien, C. (2005). Planning for sustainable happiness. Paper prepared for the 2nd International Conference on Gross National Happiness, Antigonish, Canada. www.gpiatlantic.org/conference/papers/obrien.pdf.

O'Brien, C. (2010a). Sustainability, happiness and education. Journal of Sustainability Education, 1. http://www.jsedimensions.org/wordpress/content/2010/04/.

O’Brien, C. (2010b). Sustainable happiness and health education: Teacher's guide. http://www.sustainablehappiness.ca/for-educators/.

O’Brien, C. (2012a). Teaching a university course in sustainable happiness. Solutions, May-June, 3(3). http://www.thesolutionsjournal.com/node/1108.

O'Brien, C. (2012b). Sustainable happiness and well-being: Future directions for positive psychology. Psychology, 3 (12A), 1196-1201. http://www.scirp.org/journal/PaperInformation.aspx?PaperID=26252.

O’Brien, C. (2013). Lessons in sustainable happiness. Sydney, NS: Thinking Rock.

O'Grady, P. (2013). Positive psychology in the elementary school classroom. New York: Norton and Company.

Orr, DW. (2012). Can we avoid the perfect storm? Solutions, May-June, 3(3).

http://www.thesolutionsjournal.com/node/1124.

P21.(2011). Partnership for $21^{\text {st }}$ century learning. P21 common core toolkit. http://www.p21.org/storage/documents/P21CommonCoreToolkit.pdf.

Ramanathan, S., O’Brien, C., Stone, MR., Faulkner, G., \& Cook, L. (2012). Canadian school travel planning: Wellbeing and the school journey. Canadian Public Health Association Annual Conference, Edmonton.

Rideout, V., Foehr, U., \& Roberts, D. (2010). Generation $M^{2}$ : Media in the lives of 8- to 18-year-olds. Kaiser Family Foundation Study. http://www.kff.org/entmedia/8010.cfm.

Robinson, K. (2009). The element: How finding your passion changes everything. New York: Viking.

Robinson, K. (2011). Out of our minds: Learning to be creative. Chichester, UK: Capstone.

Who is Teaching Us about Sustainable Happiness and Well-being?

Volume 5, No. 1 (2013) | ISSN 2161-6590 (online) | DOI 10.5195/hcs.2013.122 | http://hcs.pitt.edu 
Royal Government of Bhutan (2012). The Report of the high-level meeting on wellbeing and happiness: Defining a new economic paradigm. New York: The Permanent Mission of the Kingdom of Bhutan to the United Nations. Thimphu: Office of the Prime Minister. http://www.2apr.gov.bt/.

Scott, K. (2009). A literature review on sustainable lifestyles and recommendations for further research. Stockholm Environment Institute.

http://www.unep.fr/scp/marrakech/taskforces/pdf/sei_sustainable_lifestyles_evidence_report.pdf.

Seligman, M. (2002). Authentic happiness. Toronto: Free Press.

Steptoe, A., Wardle, J., \& Marmot, M. (2005). Positive affect and health-related neuroendocrine, cardiovascular, and inflammatory process. Proceedings of the National Academy of Sciences, USA 102, 6508-6512. http://www.pnas.org/content/102/18/6508.full.pdf.

Seligman, M., Ernst, R., Gillham, J., Reivich, K., and Linkins, M. (2009). Positive education: positive psychology and classroom interventions, Oxford Review of Education, 35(3), 293-311.

http://www.ppc.sas.upenn.edu/positiveeducationarticle2009.pdf.

Stewart-Brown, S. (2006). What is the evidence on school health promotion in improving health or preventing disease and, specifically, what is the effectiveness of the health promoting schools approach? Copenhagen, WHO Regional Office for Europe (Health Evidence Network report; http://www.euro.who.int/document/e88185.pdf).

Stiglitz, J., Sen, AK., \& Fitoussi, JP. (2009). 'Report by the Commission on the Measurement of Economic Performance and Social Progress', Paris. http://www.stiglitz-sen-fitoussi.fr/documents/rapport anglais.pdf.

Swayze, N., Creech, H., Buckler, C., \& Alfaro, J. (2012). Education for sustainable development in Canadian faculties of education. Report prepared for the Canadian Council for Ministers of Education. http://www.cmec.ca/Publications/Lists/Publications/Attachments/279/ESD_Dean_reportEN.pdf.

Thinley, JY. (2012). Sustainability and happiness: A development philosophy for Bhutan and the world, Solutions, May-June, 3(3). http://www.thesolutionsjournal.com/node/1121.

Turcotte, M. (2006). Like commuting? Workers' perceptions of their daily commute. Canadian Social Trends. http://www.statcan.gc.ca/pub/11-008-x/2006004/9516-eng.htm.

United Nations. (2011). Happiness should have greater role in development policy - UN Member States. UN News Centre. http://www.un.org/apps/news/story.asp?NewsID=39084.

UNEP (United Nations Environment Programme) and Marraketch Task Force on Education for Sustainable Consumption (2010). Here and now: Education for sustainable consumption. Recommendations and Guidelines. http://www.unep.fr/scp/marrakech/taskforces/pdf/H\&NMay2010.pdf.

UNEP (2011). Visions for change: Recommendations for effective policies on sustainable lifestyles. The global survey on sustainable lifestyles. Sweden: Ministry of the Environment. http://www.unep.fr/shared/publications/pdf/DTIx1321xPA-VisionsForChange\%20report.pdf.

UNESCO. (2005a). UN Decade of Education and Sustainable Development (2005 2014): Draft international implementation scheme.

portal.unesco.org/education/en/ev.phpURL_ID=36026\&URL_DO=DO_TOPIC\&URL_SECTION=201.html.

UNESCO. (2005b). Guidelines and recommendations for reorienting teacher education to address sustainability. Education for sustainable development in action. Technical paper No. 2.

http://unesdoc.unesco.org/images/0014/001433/143370E.pdf 
United Nations Secretary-General's high-level panel on global sustainability (2012). Resilient people, resilient planet: A future worth choosing. New york: United Nations.

http://www.un.org/gsp/sites/default/files/attachments/GSP_Report_web_final.pdf.

Veenhoven, R. (2006). Healthy happiness: Effects of happiness on physical health and the consequences for preventive health care, Journal of Happiness Studies, 15(11). http://link.springer.com/article/10.1007\%2Fs10902006-9042-1.

Who is Teaching Us about Sustainable Happiness and Well-being? 